\title{
Postharvest quality of strawberry fruits produced in organic and conventional systems
}

\author{
Letícia KP Camargo ${ }^{1}$; Juliano Tadeu V de Resende'; Tânia T Tominaga² ${ }^{2}$ Sonia Maria Kurchaidt ${ }^{3}$; \\ Cristhiano K Camargo ${ }^{1}$; Alex Sandro T Figueiredo ${ }^{1}$ \\ 'UNICENTRO, Depto. de Agronomia, C. Postal 3010, 85040-080 Guarapuava-PR; lpinheiro@unicentro.br; jresende@unicentro.br; \\ ccamargo@unicentro.br; fiqueiredo@hotmail.com; ${ }^{2}$ UNICENTRO, Depto. Física; ttominaga@unicentro.br; ${ }^{3}$ UNICENTRO, Depto. \\ Matemática; sonia@unicentro.br
}

\begin{abstract}
The aim of this study was to determine some physicochemical characteristics of fruits of eight strawberry cultivars (Aromas, Camino Real, Campinas, Dover, Oso Grande, Toyonoka, TudlaMilsei and Ventana) cultivated in organic and conventional systems. The evaluated characteristics were soluble solids (SS), titratable acidity (TA), SS/AT ratio and anthocyanins. Evaluated sensory characteristics were flavor and appearance. The cultivars had a differential performance between themselves and among the systems for the evaluated characteristics. Generally, the conventional system produced fruit with higher levels of soluble solids and, organic system produced higher concentrations of anthocyanins. The fruits of the cultivar Toyonoka had the best soluble solids content in both systems and the anthocyanins content of 'Tudla-Milsei' and 'Camino Real' were proeminent in comparison to the other cultivars. The fruits from the organic system of production were preferred by judges on the sensorial attributes. The highest notes were given to the appearance of the cultivar Ventana in the conventional system and 'Tudla-Milsei' in the organic system.
\end{abstract}

Keywords: Fragaria x ananassa, soluble solids, anthocyanins, sensory analysis.

\section{RESUMO}

Qualidade pós-colheita de frutos de morangueiro produzidos em sistemas orgânico e convencional

O presente trabalho teve como objetivo determinar as características químicas e sensoriais de frutos de oito cultivares de morangueiro (Aromas, Camino Real, Campinas, Dover, Oso Grande, Toyonoka, Tudla-Milsei e Ventana) provenientes de sistemas orgânico e convencional de cultivo. As características químicas avaliadas foram sólidos solúveis (SS), acidez titulável (AT), relação SS/AT e teor de antocianinas. As características sensoriais avaliadas foram sabor e aparência. As cultivares apresentaram um comportamento diferenciado entre si e frente aos sistemas de produção para as características avaliadas. De modo geral, o sistema convencional produziu frutos com maiores teores de sólidos solúveis e o sistema orgânico, maiores valores de acidez titulável e maiores concentrações de antocianinas. Os frutos da cultivar Toyonoka apresentaram o maior teor de sólidos solúveis nos dois sistemas de cultivo avaliados. Destaque para o teor de antocianinas das cultivares Tudla-Milsei e Camino Real. Quanto às características sensoriais, os frutos provenientes do sistema orgânico de produção foram preferidos pelos julgadores para os atributos avaliados. As maiores notas foram atribuídas para a aparência dos frutos da cultivar Ventana no sistema convencional e de 'Tudla-Milsei' no orgânico.

Palavras-chave: Fragaria x ananassa, sólidos solúveis, antocianinas, análise sensorial.

(Recebido para publicação em 2 de dezembro de 2010; aceito em 10 de outubro de 2011) (Received on December 2, 2010; accepted on October 10, 2011)

$\mathrm{S}_{\mathrm{p}}^{\mathrm{t}}$ trawberry cropping in conventional production systems is characterized by heavy use of synthetic chemicals including defensive chemicals that promote a substantial reduction in the fruit quality because of toxic residue. This is the reason the strawberry is on the list of foods with the highest chemical residues (Anvisa, 2008).

Using agricultural chemicals without following the technical recommendations puts human health at risk and can contaminate the environment (Darolt, 2001). Modifications caused by the use of highly soluble chemical fertilizers and toxic agricultural chemicals can cause imbalance in food nutritional quality, decrease protein production or increase the degradation of these substances (Saminêz, 2000).

Regardless of the production system, organic fertilizer is considered the fundamental for strawberry cropping because its effects go beyond benefiting the physical and biological characteristics of the soil and it is an important nutrient source. As a result microbial action develops, greater aeration and water availability develop in the soil that favor its infiltration and retention, regulate soil temperature, prevent compacting and help control erosion (Santos \& Medeiros, 2005).

Furthermore, organic fertilizer favors the absorption of synthetic fertilizers that are added to the soil to supply quinines that increase plant respiration and phenols that confer disease resistance to plants, resulting in less nutrient loss by lixiviation or formation of organic complexes with heavy metals. The interaction of these beneficial effects justifies the favorable responses of the crop to organic fertilization (Ronque, 1998).

Thus with organic fertilization, a fundamental component for organic production, it is expected that the foods 
produced in this system would have greater nutritional value because they are produced from a richer, nutrientbalanced soil (Darolt, 2003).

According to Williams (2002), there are few studies that compare the nutrient compositions of organically and conventionally produced foods. Regarding the nutritional quality, there is still no consensus on the superiority organic products for most nutrients. However, positive tendencies can be observed for some characteristics.

The parameters to determine nutritional quality are multifactorial, so soil conditions, climate and within and among cultivar genetic variability can show significantly different responses in function of the cropping system adopted, whether conventional or organic (Darolt, 2003).

According to Darolt (2003), comparative studies on sensory quality among products from organic and conventional systems, that assess flavor, smell and acidity have not been very conclusive when compared to products from conventional cropping.

Thus the objective of the present study was to characterize chemically and assess the acceptability of fruits from the different strawberry cultivars cropped in organic and conventional systems.

\section{MATERIAL AND METHODS}

The experiment was carried out in the Olericulture Sector of the Department of Agronomy at the State University of the Center-West (UNICENTRO) (2523'36"'S, 51 27 '19' W, 1,120 m altitude), Paraná state, Brazil. The experiment was carried out in soil classified as Dystric Red-Yellow Latossol (Embrapa, 2006), and the climate in the location is $\mathrm{Cfb}$ warm wet subtropical, with cool summers, winters with frequent severe frosts and no dry season (Köppen classification). The mean annual temperature is $17.1^{\circ} \mathrm{C}$ and the mean annual rainfall is around 1953 mm (Thomaz \& Vestena, 2003).

The experiment was conducted in two production systems, organic and conventional. The area where the organic production system was installed was isolated by a physical barrier and has been submitted to the specific practices permitted for the system for over five years. Considering the chemical analysis of the soil, we applied before planting the seedlings, per plot: $25 \mathrm{~kg}$ cattle manure, $100 \mathrm{~g}$ agricultural chalk and $150 \mathrm{~g}$ natural rock phosphate and Supermagro (40 $\mathrm{kg}$ fresh manure, $2 \mathrm{~kg} \mathrm{ZnSO}_{4}, 300 \mathrm{~g}$ $\mathrm{S}, 1 \mathrm{~kg} \mathrm{MgSO}_{4}, 500 \mathrm{~g} \mathrm{CaHPO}_{4}, 100$ g $\mathrm{NaMoO}_{4} \cdot 2 \mathrm{H}_{2} \mathrm{O}, 50 \mathrm{~g} \mathrm{CoSO} \cdot 6 \mathrm{H}_{2} \mathrm{O}$, $300 \mathrm{~g} \mathrm{FeSO}_{4}, 300 \mathrm{~g} \mathrm{MnSO}_{4}, 300 \mathrm{~g}$ $\mathrm{CuSO}_{4}, 4 \mathrm{~kg}$ lime, $1.5 \mathrm{~kg} \mathrm{H}_{3} \mathrm{BO}_{3}, 160 \mathrm{~g}$ cofermol, $2.4 \mathrm{~kg}$ natural phosphate and $1.2 \mathrm{~kg}$ ash) was used for the maintenance fertilizations at the concentration of 100 $\mathrm{mL}$ for $5 \mathrm{~L}$ water sprayed every 15 days. The other crop treatments, including trimming to improve the sun incidence and aeration of the plant, were carried out whenever necessary. Products were used for pest and disease control permitted by the Normative Instruction $\mathrm{n}^{\circ}$ 07, 17 May 1999 of the Ministry of Agriculture, Fishing and Supply for organic production systems.

The following were applied for cropping in the conventional system, before planting the seedlings according to the soil analysis: $400 \mathrm{~g}$ simple superphosphate, $100 \mathrm{~g}$ agricultural chalk, $50 \mathrm{~g}$ potassium chloride, $50 \mathrm{~g}$ urea and $5 \mathrm{~kg}$ cattle manure, as recommended by Raij et al. (1996). As in the organic cropping system, the plants were also trimmed to improve insolation and aeration. For reposition fertilization the following were applied: $30 \mathrm{~g}$ of the NPK 04-14-08 formula at 30, 60 and 90 days after transplanting and $40 \mathrm{~g}$ urea were applied every 20 days per plot until the end of the productive cycle. Deltamethrin, abamectin and acephate were applied alternately whenever necessary for pest control (mites and aphids) at the doses recommended for the crop. Iprodione, tebuconazole and dithiocarbamate were applied for preventative fungus disease control (leaf spot, anthracnose and powdery mildew). Leaf fertilizer was applied based on calcium and borum at $100 \mathrm{~mL}$ for 10 $\mathrm{L}$ water during the fructification phase.

A randomized block design was used for the field experiment with four replications. The plot consisted of a 2 $\mathrm{m}^{2}$ useful area consisting of 18 plants, spaced at $0.30 \mathrm{~m}$ in a triangle according to recommendations for the crop by Ronque (1998). All the plants in the plot were considered useful because fertilization did not vary among the treatments.

The beds were $16 \mathrm{~m}$ long, $1.00 \mathrm{~m}$ wide, $0.35 \mathrm{~m}$ high and spaced at 0.40 m. Drip tube irrigation was used with nozzles placed at $0.30 \mathrm{~m}$. The seedlings were transplanted on July 1 and after they had rooted 30 micra black plastic film (mulching) was fastened over the beds as recommended for the crop. About 10 days later, the plants placed in the beds were protected from bad weather by 150 micra thick transparent plastic film in the form of tunnels, 0.80 $\mathrm{m}$ high from the bed surface.

The following strawberry cultivars were used: Aromas, Camino Real, Campinas, Dover, Oso Grande, Toyonoka, Tudla-Milsei and Ventana.

The chemical analyses were realized in triplicate on frozen fruit $\left(-18^{\circ} \mathrm{C}\right)$. Fruits were collected from all the plot, when three quarters of the surface was at the dark red stage. The fruits were frozen immediately after collection, from the start to the end of the cropping cycle. Approximately $500 \mathrm{~g}$ fruits were ground in a domestic centrifuge for the soluble solid contents, titratable acidity and anthocyanin analyses.

The soluble solid content was determined by a direct reading at environmental temperature in a manual Instrutherm Refractometer, model RT30ATC, and expressed in degrees Brix.

Samples of $10 \mathrm{~g}$ were used to determine the titratable acidity, approximately $100 \mathrm{~mL}$ distilled water and two drops of phenolphthalein and the solution was titrated with a standard $\mathrm{NaOH} 0.1 \mathrm{~N}$ solution. A pH gauge was used to determine the equivalence point until a value close to 8.3 was reached, which is the phenolphthalein equivalence point. The data were expressed in percentage of citric acid (Instituto Adolfo Lutz, 1985).

The SS/AT ratio was determined by dividing the soluble solid contents values by the titratable acidity values. 
The monomeric anthocyanin concentration was determined by the pH-differential method (Giusti \& Wrolstad, 2001), with dilution in two buffer systems, that are potassium chloride $\mathrm{pH} 1.0(0.025 \mathrm{M})$ and sodium acetate $\mathrm{pH} 4.5$ (0.4 M). The sample dilution consisted of $20 \mathrm{~g}$ fruit added to $32 \mathrm{~mL}$ distilled water and this solution was then filtered. Aliquots of $0.3 \mathrm{~mL}$ were removed from the filtered solution and added to $2.7 \mathrm{~mL}$ of the buffer solutions, separately. The samples were analyzed at 510 and $700 \mathrm{~nm}$ in a UV-VIS spectrophotometer (Varian model Cary 50 Bio) and the equation proposed by Giusti \& Wrolstad (2001) was applied: monomeric anthocyanins pigment $=\mathrm{A} / \varepsilon \times \mathrm{DF} \times \mathrm{MW} \times 100$, where $A$ is the reading value in absorbance, $\varepsilon$ is the molar absorptivity of cyanidin-3glucoside, DF is the dilution factor of the sample and MW is the molecular weight of cyanidin-3-glucoside. The results were expressed in mg cyanidin3-glucoside /100 g sample.

The sensory analyses were carried out on 02/01/2008, in the Santa Cruz Campus, at UNICENTRO. The fruits used for the sensory analysis were collected and washed immediately in solution with $1.5 \%$ sodium hypochlorite for 10 minutes to prepare the sample. The sensory panel consisted of 52 untrained judges that are potential consumers of the product in question and were professors and staff of UNICENTRO and the community in general.

Each judge was given trays with four strawberry samples in lidded plastic recipients, codified with three random digital numbers. They were asked to rank the samples, according to preference and using a record card, for the least preferred (score 1) to the most preferred (score 5) regarding the flavor attribute (Ferreira, 1999).

To assess the appearance, the fruits of each cultivar codified with three random digital numbers were presented on expanded polystyrene trays covered with transparent PVC film placed on a sample table under white light. According to preference and using a record card, each judge was asked to choose the expression that would best represent the sample, and the hedonic scale was anchored on the extremes by "I liked it very much" (score 9) and "I really didn't like it" (score 1) (Ferreira, 1999).

The sensory tests used were rankingpreference for the flavor attribute and a hedonic scale of nine points was used for appearance.

The statistical design used to randomize the samples for the sensory analysis was a lattice or imbalanced incomplete block design with 13 replications due to the high number of samples (16 samples $=$ two production systems and eight cultivars), considering sensory fatigue on the part of the judges.

The data means of the chemical and sensory analyses were compared by the Tukey test at 5\% probability and the means among the production systems were compared by the t-test at $5 \%$ probability. It is emphasized that the statistical treatment of the sensory data was not carried out in a lattice design because of the low efficiency $(<100 \%)$ in randomized blocks.

\section{RESULTS AND DISCUSSION}

Considering the comparison between the conventional and organic production systems for the soluble solid content it can be stated that only the fruits of the Aromas cultivar presented greater content in the organic $\left(7.33^{\circ} \mathrm{Brix}\right)$ than in the conventional system. 'Camino Real' (7.96 ${ }^{\circ}$ Brix), 'Dover' ( $7.93{ }^{\circ}$ Brix $)$ and 'Oso Grande' ( $8.50^{\circ}$ Brix $)$ produced fruits with greater soluble solid content in the conventional system. There was no significant difference among the other cultivars for this characteristic (Table 1). The soluble solid content has a tendency to increase with ripeness. It consists mainly of sugars, and varies with the species, cultivar, ripeness stage and climate (Chitarra \& Chitarra, 2005).

In the conventional system the “Toyonoka' fruits were outstanding for soluble solid content (9.83 ${ }^{\circ}$ Brix), differing from all the other cultivars. This was expected because this cultivar is characterized by an excellent flavor that is certainly related to the soluble solid content (Ronque, 1998; Chitarra \& Chitarra, 2005). At the other extreme, the fruits from the Aromas cultivar had the lowest soluble solid contents (7.03 Brix). Similar performance was observed in the organic system, when again the fruits from the Toyonoka cultivar were outstanding compared to the others, presenting high soluble solid content (10.00 Brix).

Fruits of the Honor cultivar, from organic and conventional managements, when assessed for soluble solids contents by Abu-Zahra et al. (2007), were shown to be superior in the organic system, and varied from 6.91 to 7.09 Brix in the organic system, while the fruit from the conventional system had 6.61 mean Brix. Krolow et al. (2007) also compared the soluble solid content of fruit of the Aromas cultivar from different cropping systems and reported a superiority of $16.1 \%$ for fruit in the organic system thus corroborating the results of the present study for this cultivar. The mean of the soluble solid contents for the conventional system determined by these authors was 6.20 Brix and 7.20 Brix for the organic system, while in the present study it was 7.03 Brix for the conventional and 7.33 Brix for the organic system.

For titratable acidity we observed that the fruits from the Campinas and Tudla-Milsei cultivars presented the highest percentages in the organic system, but the production system did not influence the acidity content in the other cultivars (Table 1). It can be stated that the fruits rapidly lose acidity with ripening, but in some cases there is a small increase in the values as ripeness advances (Chitarra \& Chitarra, 2005), and this might explain the difference in acidity among the cultivars assessed.

In the conventional system 'TudlaMilsei' was a cultivar that presented fruits with greater titratable acidity $(1.12 \%)$ differing significantly from the others and 'Campinas' presented the least acidity $(0.88 \%)$, but it also differed statistically from the other cultivars. For the organic system again the fruits from the Tudla-Milsei cultivar were more acid (1.21\%) differing from the other cultivars assessed. Thus like the soluble solid contents it was presumed that there was also cultivar-environment interaction. 
Table 1. Means of soluble solid contents, titratable acidity, SS/AT ratio and anthocyanins content of fruits from strawberry cultivars in the conventional and organic systems (médias dos teores de sólidos solúveis ( ${ }^{\circ}$ Brix), acidez titulável (\% ácido cítrico), relação SS/AT e antocianinas (mg cianidina-3-glicosídeo/100g amostra) de cultivares de morango avaliadas nos sistemas convencional e orgânico de cultivo). Guarapuava, UNICENTRO, 2008.

\begin{tabular}{|c|c|c|c|c|}
\hline \multirow{2}{*}{ Cultivar } & Conventional & Organic & Conventional & Organic \\
\hline & \multicolumn{2}{|c|}{ SS content $\left({ }^{\circ}\right.$ Brix $)$} & \multicolumn{2}{|c|}{ Titratable acidity (\% citric acid) } \\
\hline Aromas & $7.03 * \mathrm{Bd}$ & $7.33 \mathrm{Ad}$ & $0.97 * \mathrm{Abc}$ & 0.93 Ac \\
\hline Campinas & $8.56 \mathrm{Ab}$ & $8.40 \mathrm{Ab}$ & $0.88 \mathrm{Bd}$ & $0.95 \mathrm{Ac}$ \\
\hline Camino Real & $7.96 \mathrm{Ac}$ & $7.40 \mathrm{Bd}$ & $0.94 \mathrm{Ac}$ & $0.91 \mathrm{Ac}$ \\
\hline Dover & $7.93 \mathrm{Ac}$ & $7.26 \mathrm{Bd}$ & $1.01 \mathrm{Ab}$ & $1.05 \mathrm{Ab}$ \\
\hline Oso Grande & $8.50 \mathrm{Ab}$ & $8.06 \mathrm{Bc}$ & $0.97 \mathrm{Abc}$ & $0.93 \mathrm{Ac}$ \\
\hline Toyonoka & $9.83 \mathrm{Aa}$ & $10.00 \mathrm{Aa}$ & $1.01 \mathrm{Ab}$ & $1.04 \mathrm{Ab}$ \\
\hline Tudla-Milsei & 8.10 Ac & $7.90 \mathrm{Aa}$ & $1.12 \mathrm{Ba}$ & $1.21 \mathrm{Aa}$ \\
\hline \multirow[t]{2}{*}{ Ventana } & $8.76 \mathrm{Ab}$ & $8.10 \mathrm{Aa}$ & $0.99 \mathrm{Abc}$ & $1.01 \mathrm{Ab}$ \\
\hline & \multicolumn{2}{|c|}{ SS/AT ratio } & \multicolumn{2}{|c|}{$\begin{array}{c}\text { Anthocyanins } \\
\text { (mg cyanidin-3-glucoside/100g sample) }\end{array}$} \\
\hline Aromas & $7.24 * \mathrm{Bd}$ & $7.88 \mathrm{Ac}$ & $34.10^{*} \mathrm{Bc}$ & 37.20 Ac \\
\hline Campinas & $9.72 \mathrm{Aa}$ & $8.84 \mathrm{Bb}$ & $28.10 \mathrm{Bd}$ & 33.20 Acd \\
\hline Camino Real & $8.47 \mathrm{Ab}$ & $8.13 \mathrm{Bc}$ & $48.20 \mathrm{Ba}$ & $52.30 \mathrm{Aa}$ \\
\hline Dover & $7.85 \mathrm{Ac}$ & $6.91 \mathrm{Bd}$ & $40.50 \mathrm{Bb}$ & $45.30 \mathrm{Ab}$ \\
\hline Oso Grande & $8.76 \mathrm{Ab}$ & $8.67 \mathrm{Ab}$ & $38.90 \mathrm{Bb}$ & $41.60 \mathrm{Ab}$ \\
\hline Toyonoka & $9.74 \mathrm{Aa}$ & $9.61 \mathrm{Aa}$ & $14.90 \mathrm{Be}$ & $16.50 \mathrm{Ae}$ \\
\hline Tudla-Milsei & $7.23 \mathrm{Ad}$ & $6.52 \mathrm{Bd}$ & $51.00 \mathrm{Aa}$ & $44.00 \mathrm{Bb}$ \\
\hline Ventana & $8.85 \mathrm{Ab}$ & $8.01 \mathrm{Bc}$ & $32.40 \mathrm{Ac}$ & $29.90 \mathrm{Bd}$ \\
\hline
\end{tabular}

*Means followed by the same lowercase letter in the column do not differ statistically by the Tukey test $(p<0,05)$ and uppercase letters on the line do not differ statistically by the t-test (médias seguidas de mesma letra minúscula na coluna não diferem estatisticamente entre si $(\mathrm{p}<0,05)$ pelo teste de Tukey e maiúscula na linha não diferem estatisticamente entre si $(\mathrm{p}<0,05)$ pelo teste $\mathrm{t})$.

Table 2. Mean scores attributed by the assessors to the flavor and appearance attributes of fruits from strawberry cultivars assessed in the conventional and organic system cropping systems by ordering tests preference ( 1 to 5 notes) and hedonic scale to nine points (médias das notas atribuídas pelos julgadores aos atributos sabor e aparência de frutos de cultivares de morango avaliadas nos sistemas convencional e orgânico de cultivo pelos testes de ordenação-preferência (notas de 1 a 5) e escala hedônica de nove pontos, respectivamente). Guarapuava, UNICENTRO, 2008.

\begin{tabular}{|c|c|c|c|c|c|c|c|c|}
\hline \multirow{3}{*}{$\begin{array}{l}\text { Cultivar } \\
\text { Aromas }\end{array}$} & \multicolumn{2}{|c|}{ Conventional } & \multicolumn{2}{|c|}{ Organic } & \multicolumn{2}{|c|}{ Conventional } & \multicolumn{2}{|c|}{ Organic } \\
\hline & \multicolumn{4}{|c|}{ Flavor } & \multicolumn{4}{|c|}{ Appearance } \\
\hline & 2.31 & $\mathrm{Ba}$ & 3.00 & $\mathrm{Aa}$ & 6.30 & Aabc & 5.84 & $\mathrm{Aab}$ \\
\hline Campinas & 2.53 & Aa & 2.15 & $\mathrm{Ba}$ & 4.15 & $\mathrm{Ac}$ & 4.61 & $\mathrm{Ab}$ \\
\hline Camino Real & 2.15 & $\mathrm{Ba}$ & 3.00 & $\mathrm{Aa}$ & 4.92 & $\mathrm{Babc}$ & 6.38 & $\mathrm{Aab}$ \\
\hline Dover & 2.15 & $\mathrm{Ba}$ & 2.77 & $\mathrm{Aa}$ & 6.92 & Aab & 6.30 & $\mathrm{Aab}$ \\
\hline Oso Grande & 3.37 & $\mathrm{Aa}$ & 2.53 & $\mathrm{Ba}$ & 4.85 & $\mathrm{Bbc}$ & 5.62 & $\mathrm{Aab}$ \\
\hline Toyonoka & 2.53 & $\mathrm{Aa}$ & 2.23 & $\mathrm{Ba}$ & 6.53 & Aab & 5.69 & $\mathrm{Bab}$ \\
\hline Tudla-Milsei & 2.15 & Aa & 1.83 & $\mathrm{Ba}$ & 6.92 & Aab & 7.54 & $\mathrm{Aa}$ \\
\hline Ventana & 2.76 & $\mathrm{Aa}$ & 2.69 & $\mathrm{Aa}$ & 7.23 & $\mathrm{Aa}$ & 5.92 & $\mathrm{Bab}$ \\
\hline
\end{tabular}

*Means followed by the same lowercase letter in the column do not differ statistically by the Tukey test $(\mathrm{p}<0,05)$ and uppercase letters on the line do not differ statistically by the t-test (médias seguidas de mesma letra minúscula na coluna não diferem estatisticamente entre si $(\mathrm{p}<0,05)$ pelo teste de Tukey e maiúscula na linha não diferem estatisticamente entre si $(\mathrm{p}<0,05)$ pelo teste $\mathrm{t})$.

Krolow et al. (2007) determined acidity in fruits from the Aromas cultivar and found a $5.2 \%$ smaller difference for fruits grown in the organic system compared to the conventional system. The result corroborates with that of the present study, because a small percentage difference was observed between the Aromas cultivar fruits for the titratable acidity characteristic and the lowest percentage was observed in the fruits from the organic system.

Abu-Zahra et al. (2007) determined the acidity for the fruits from the Honor cultivar and observed $0.99 \%$ acidity 
Table 3. Values of correlation between SS/AT ratio and flavor attribute, anthocyanins and appearance attribute, of fruits from strawberry cultivars assessed in the conventional and organic cropping systems (valores de correlação entre a relação SS/AT e o atributo sensorial sabor e entre os teores de antocianinas (mg cianidina-3-glicosídeo $100 \mathrm{~g}^{-1}$ amostra) e o atributo sensorial aparência, de frutos de cultivares de morango avaliadas nos sistemas convencional e orgânico de cultivo). Guarapuava, UNICENTRO, 2008.

\begin{tabular}{lcccccc}
\hline \multirow{2}{*}{ Cultivar } & \multicolumn{2}{c}{ SS/AT x flavor } & & \multicolumn{2}{c}{ Anthocyanins x appearance } \\
\cline { 2 - 3 } \cline { 5 - 6 } \cline { 5 - 6 } \cline { 5 - 6 } Aromas & Conventional & Organic & & Conventional & Organic \\
Campinas & $0.97^{*}$ & $-0.23^{\text {ns }}$ & & $-0.72^{*}$ & $0.43^{\text {ns }}$ \\
Camino Real & $0.80^{*}$ & $0.52^{*}$ & & $-0.62^{*}$ & $-0.74^{*}$ \\
Dover & $-0.99^{*}$ & $-0.85^{\text {ns }}$ & & $-0.98^{*}$ & $-0.76^{*}$ \\
Oso Grande & $0.79^{*}$ & $0.46^{\text {ns }}$ & & $-0.47^{\text {ns }}$ & $-0.87^{*}$ \\
Toyonoka & $0.81^{*}$ & $0.90^{*}$ & & $0.23^{\text {ns }}$ & $0.86^{*}$ \\
Tudla-Milsei & $0.99^{*}$ & $0.90^{*}$ & & $0.81^{*}$ & $0.86^{*}$ \\
Ventana & $-0.09^{\text {ns }}$ & $-0.40^{\text {ns }}$ & & $-0.15^{\text {ns }}$ & $0.90^{*}$ \\
\cline { 1 - 3 } & $0.84^{*}$ & $0.30^{\text {ns }}$ & & $0.75^{*}$ & $0.80^{*}$ \\
\hline
\end{tabular}

*Significant by the t-test ( $\mathrm{p} \geq 0,05)$ [Significativo pelo teste $\mathrm{t}(\mathrm{p} \geq 0,05)$ ] ( ${ }^{\mathrm{ns} N o t}$ significant by the t-test $(p \geq 0,05)$ [Não significativo pelo teste $t(p \geq 0,05)]$.

in the conventional system and in the organic system the acidity ranged from 0.93 to $0.96 \%$.

Regarding the values of the soluble solids:titratable acidity ratio (SS/TA) comparison of the production systems adopted showed that the conventional system was more effective in increasing this ratio for the fruits of the Campinas, Camino Real, Dover, Tudla-Milsei and Ventana cultivars. The fruits from 'Aromas' had the lowest SS/ TA ratio in the organic system while the fruits from 'Oso Grande' and 'Toyonoka' were not influenced by the management adopted. Taking into consideration that the ratio indicated balance between the two components, specifying the minimum solid contents on the maximum acidity to determine the real flavor most accurately. For the strawberry commercially, the minimum soluble solids content (\%) is 7.0 and the maximum titratable acidity content (\%) is 8.0 (Chitarra \& Chitarra, 2005), resulting in an $8.75 \mathrm{SS} / \mathrm{TA}$, a value reached only by some of the cultivars tested in the present study.

The best balance among the sweet and acid constituents, in both the conventional and organic systems, was attributed to the fruits from the Toyonoka cultivar. In the conventional system, the Toyonoka fruits had a 9.74 SS/TA ratio and in the organic system of 9.61. It is pointed out that in the organic the fruit, because all the three cultivars tested by Dias et al. (2006) presented a low SS/TA ratio.

For the anthocyanin concentration, except for the fruits from the TudlaMilsei and Ventana cultivars, the others ('Aromas', 'Campinas', 'Camino Real', 'Dover', 'Oso Grande' and 'Toyonoka') presented the highest contents in the organic system (Table 1).

In the conventional system, the cultivars that were outstanding for anthocyanin values were Tudla-Milsei and Camino Real, with 51.00 and $48.20 \mathrm{mg}$ cyanidin-3-glucoside $/ 100 \mathrm{~g}$ sample, respectively, and the fruits from 'Toyonoka' presented the lowest content of these highly colored pigments, 14.90 cyanidin-3-glucoside/100g sample. In the organic system, the cultivar performance for the characteristic analyzed was similar. The fruits of the Camino Real cultivar, known for their dark red coloring, presented 52.30 cyanidin-3-glucoside/100g sample and the Toyonoka fruits were again quantified with the lowest anthocyanin contents.

The low anthocyanin concentration and consequently pale coloring was explained by Shaw (2004) when he stated that the fruit coloring of the Toyonoka cultivar in agricultural years with cooler temperatures becomes more pronounced and tends to be bright red. Cropping in a protected environment during the spring/summer contributed to the increase in temperature that presumably resulted in a less bright coloring in this cultivar showing its high sensitivity to high temperatures when compared to the others.

Indeed, during the development of the present study, from July 2007 to February 2008, according to data from the Meteorological Station on the Cedeteg Campus, UNICENTRO, the temperatures were high, even in the winter, when the mean minimum was $15.5^{\circ} \mathrm{C}$, above the critical level reported by Ronque (1998) for the strawberry crop that is $11.4^{\circ} \mathrm{C}$.

A $106.1 \%$ difference from the organic to the conventional system was observed by Krolow et al. (2007) for the anthocyanin contents of the Aromas cultivar. In the conventional 
system they observed $17.60 \mathrm{mg} / 100 \mathrm{~g}$ sample and in the organic system 36.29 $\mathrm{mg} / 100 \mathrm{~g}$ sample. In the present study, a smaller difference from the organic system to the conventional system was observed for the same cultivar, only $8.3 \%$ in favor of the organic management. The difference among the anthocyanin contents in the same cultivar for different cropping regions can be explained by the environmental factor of luminosity. According to Chitarra \& Chitarra (2005) insufficient luminosity effects coloring development because it affects pigment synthesis.

According to Abu-Zahra et al. (2007), fruits of the Honor cultivar presented anthocyanin values ranging from 38.89 and 42.88 pelargonidin-3glucoside/100g sample when cropped in different concentrations of organic material in the soil in an organic system and $39.34 \mathrm{mg} / 100 \mathrm{~g}$ sample in the conventional system. Chitarra \& Chitarra (2005) explained that variation in color, and consequently in the quantity of the anthocyanin pigment, is common among cultivars of the same species.

Regarding the sensory attribute flavor, Table 2 shows the means of the scores attributed by the judges. The cropping system did not influence the judges preference except for the fruits of the Ventana cultivar because there was no significant difference among the means of the cropping systems. The fruits of 'Aromas', 'Camino Real' and 'Dover' were preferred when cropped in the organic system and 'Campinas', 'Oso Grande' and 'Toyonoka' in the conventional system.

Abu-Zahra et al. (2007) assessed the flavor of Honor cultivar fruits cropped in conventional and organic systems and did not observe significant differences between the treatments although the highest scores were attributed to fruits from the organic system. This fact was explained by Darolt (2003), who reported the difficulty of judges in sensory analysis to state that there are significant differences between cultivars of the same species produced by different cropping systems.

Although significant differences were not observed among the cultivars from the different cropping systems,
Bittencourt (2006) observed when assessing the flavor of fruit from cultivars produced in different systems that although the product was purchased for appearance, the equality perceived by the palate is more important for consumers.

Table 2 shows that the fruits from the Camino Real and Oso Grande cultivars were preferred and received the highest scores for appearance in the organic system and 'Toyonoka' and 'Ventana' in the conventional system.

The Campinas cultivar received the lowest scores and had the lowest mean (4.15) in both the conventional and organic system (4.61) and the TudlaMilsei cultivar had the highest mean (7.54) in the organic system. It can be stated that the Campinas cultivar did not please the judges for appearance for fruits from either cropping system in the fruit assessment. This factor can be explained by the genetic characteristics of the cultivar itself, that has a soft textured pulp and therefore poor postharvest conservation and the epidermis is a mid-red color (Shaw, 2004) that does not make the fruit very attractive to the consumer.

Abu-Zahra et al. (2007) observed the best scores for strawberry fruit appearance in the Honor cultivar in the organic system for the treatment with the greatest organic matter application. These authors stated that generally, the treatments with different organic matter concentrations presented the highest scores compared to the conventional system, but without significant differences. These data corroborate somewhat the results reported in the present study, because most of the cultivars scored highest when in the organic system, presumably because they came from a more balanced soil and thus produced fruits of a better standard.

In order to report some chemical and sensory factors responsible for the strawberry fruit quality, Table 3 shows the correlation values between the soluble solid content:titratable acidity ratio (SS/TA) with the flavor attribute. In the conventional system, the Toyonoka (0.99) and Aromas (0.97) cultivars had the highest positive correlation for fruit flavor. However, 'Camino Real' had a high negative correlation of the SS/TA ratio with flavor (-0.99), indicating that the sugar and acid contents present in the fruit pulp negatively influenced the flavor acceptance. Resende et al. (2008) observed that the balance between the sweet and acid constituents was strongly related to the perception of flavor by the judges when they correlated the same chemical characteristics with the flavor of different strawberry cultivars.

In the organic system, the fruits of the cultivars that were most influenced by the balance between SS and TA with fruit flavor were 'Oso Grande' (0.90) and 'Toyonoka' $(0.90)$. It can be stated that the fruit flavor of 'Toyonoka' and 'Oso Grande' was positively influenced by the chemical variables. Again, 'Camino Real' had a high negative correlation between fruit flavor and the sweet and acid constituent balance (-0.85). According to Chitarra \& Chitarra (2005), the differences in flavor and aroma among species and even among cultivars are related to some specific predominant substances and their proportion in the products.

The correlation between the anthocyanin content and fruit appearance can indicate that acceptance by the judges was related to the food coloring and therefore influenced by the pigment concentration. Thus in the conventional cropping system, the Toyonoka (0.81) and Ventana $(0.75)$ cultivars presented the highest correlation between coloring and appearance (Table 3). 'Camino Real' had the highest, but negative, correlation value (-0.98), probably because the judges associated the dark red color of the fruit to deterioration processes because even though the fruits had been collected at the same ripeness stage the characteristic coloring of each cultivar can vary. In the organic system 'Tudla' (0.90), 'Toyonoka' (0.86) and 'Oso Grande' (0.86) had the greatest positive influence from coloring in fruit appearance. Dover had the highest negative value for correlation between appearance and anthocyanin content $(-0.87)$ that indicated that the coloring of its fruit was not favorable for the appearance attribute.

For strawberry fruits to be well accepted for flavor, there must be a 
positive correlation among the soluble solids and titratable acidity contents because according to Chitarra \& Chitarra (2005), the combination between sweetness, acidity and astringency along with the fruit aroma supply the perception of flavor to the consumer.

It was concluded from the results reported in the present study that the cultivars performed very differently within each cropping system and between each other.

Generally, the conventional system produced fruits with greater soluble solid contents while the organic system produced fruit with greater titratable acidity and anthocyanin contents. The strawberry fruits cropped in the organic system received the highest scores from the judges in the sensory analysis. The soluble solids contents in the fruits of the Toyonoka cultivar, the anthocyanin content in the 'Tudla-Milsei' and 'Camino Real' and the fruit appearance from 'Ventana' and 'Tudla-Milsei' cultivars were outstanding.

\section{REFERENCES}

ABU-ZAHRA TR; AL-ISMAIL K; SHATAT F. 2007. Effect of organic and conventional systems on fruit quality of strawberry (Fragaria $\mathrm{x}$ ananassa Duch) grown under plastic house conditions in the Jordan Valley. Acta Horticulturae 741: 159-171.

ANVISA. 2008, 08 de junho. Programa de Análise de Resíduos de Agrotóxicos em

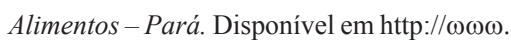

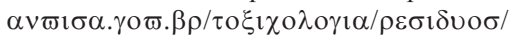
$\rho \varepsilon \sigma \nu \lambda \tau \alpha \delta \circ \sigma \Pi \alpha \rho \alpha . \eta \tau \mu l$.

BITTENCOURT KMVA. 2006. O consumidor responde sobre a aparência e o sabor de diferentes cultivares de morango. APTA - Agência Paulista de Tecnologia dos Agronegócios, Pólo Regional do Leste Paulista-UPD, Monte Alegre do Sul.

CHITARRA MIF; CHITARRA AB. 2005. Póscolheita de frutas e hortaliças: Fisiologia e Manuseio. Lavras: UFLA. 785 p.

DAROLT MR. 2001, 02 de março. Morango: sistema orgânico apresenta viabilidade técnica, econômica e ecológica. Disponível em http//www.planetaorganico.com.br/ darmorang.html.

DAROLT MR. 2003. Comparação da qualidade do alimento orgânico com o convencional. In: STRIGHETA PC; MUNIZ JN (eds). Alimentos orgânicos: produção, tecnologia e certificação. Viçosa: UFV. p.289-312.

DIAS MSC; RIBEIRO JÚNIOR PM; SILVA MS; SANTOS LO; CANUTO RS; CASTRO MV; COSTA SM. 2006. Caracterização físicoquímica de morangos cultivados na região norte de Minas Gerais. In: VXII Congresso Brasileiro de Fruticultura, Pelotas, 2006. Anais... Pelotas:UFPEL.

EMBRAPA. 2006. Centro Nacional de Pesquisa de Solos. Sistema brasileiro de classificação de solos. $2^{\mathrm{a}}$ ed. Rio de Janeiro, $306 \mathrm{p}$.

FERREIRA VLP. 1999. Análise sensorial: testes discriminativos e afetivos. São Paulo: PROFÍQUA; Campinas; SBCTA, 109p. (Manual série qualidade).

GIUSTI MM; WROLSTAD RE. 2001. Anthocyanins: characterization and measurement with uv-visible spectroscopy. In: WROLSTAD RE (ed). Current protocols in food analytical chemistry. New York, F1.2:1-13.

INSTITUTO ADOLFO LUTZ. 1985. Normas analíticas do Instituto Adolfo Lutz: métodos químicos e físicos para análises de alimentos. 3 ed. São Paulo. 371p.

KROLOW AC; SCHWENGBER J; FERRI N. 2007. Avaliações físicas e químicas de morangos cv. Aromas produzidos em sistema orgânico e convencional. Revista Brasileira de Agroecologia 2: 1732-1735.

RAIJ B; CANTARELLA H; QUAGGIO JA; FURLANI AMC (ed). 1996. Recomendações de adubação a calagem para o Estado de São Paulo. $2^{\mathrm{a}}$ Edição. Campinas: IAC, p. 237-239. (Boletim Técnico 100).

RESENDE JTV; CAMARGO LKP; ARGANDOÑA EJS; MARCHESE A; CAMARGO CK. 2008. Sensory analysis and chemical characterization of strawberry fruits. Horticultura Brasileira 26:371-374.

RONQUE ERV. 1998. A cultura do morangueiro. Curitiba: EMATER/PR. 206p.

SAMINÊZ TCO. 2000. Agricultura orgânica: mercado em expansão. Revista Brasileira Agropecuária, ano I, n.9.

SANTOS AM; MEDEIROS ARM. 2005. Nutrição, calagem e adubação. In: Sistema de produção do morango. Sistemas de produção - 5, versão eletrônica, EMBRAPA CLIMA TEMPERADO.

SCHOPPLEIN E; KRUGER E; RECHNER A; HOBERG E. 2002. Analytical and sensory qualities of strawberry cultivars. Acta Horticulturae, 567:805-807.

SHAW DV. 2004. Strawberry production systems, breeding and cultivars in California. In: SIMPÓSIO NACIONAL DO MORANGO, 2; ENCONTRO DE PEQUENAS FRUTAS E FRUTAS NATIVAS, 1. Palestras... Pelotas: EMBRAPA CLIMA TEMPRADO. p.15-20. (Embrapa Clima Temperado. Documentos, 124).

THOMAZ EL; VESTENA LR. 2003. Aspectos climáticos de Guarapuava-PR. Guarapuava: UNICENTRO, $106 \mathrm{p}$.

WILLIAMS CM. 2002. Nutritional quality of organic food: shade of grey or shades of green? Proceedings of the Nutrition Society 61:19-24. 